\title{
IMPACT OF MERGERS \& ACQUISITIONS ON FINANCIAL PERFORMANCE A STUDY OF SELECT INDIAN COMPANIES
}

*Samiya Mubeen

\author{
**Dr. Y. Nagaraju
}

\section{Abstract}

Many studies revealed the fact that Mergers and Acquisitions (M\&A) are a risky business. The corporate evaluations show that most of the companies which completed M\&A transactions disappoint to deliver on promised financial performance. But, it is an investment and the highest risks produce the highest results whether they're success or failure. The aim of this paper is to study the impact of M\&A on the financial performance of select acquirer companies in India. The objective is to analyze the impact of M\&A on profitability, growth and liquidity position. The analysis is done based on the financial performance of select Indian companies for five years pre- and post-merger. The selected ten Indian Companies which have undergone M\&A during 2006-2016 is taken as sample size. The secondary data for five years pre- and post-merger collected from annual audited financial statements from 2000-2017. To assess the profitability, growth and liquidity position in the select companies,appropriate financial ratios have been used. The data analysis is made with the help of a statistical tool, for the data analysis paired $t$ test used by SPSS software to test the significance level. The findings of this study show that there is no improvement in financial performance of acquirer companies after M\&A.

Keywords: Mergers, Acquisition, Financial Performance, Ratio Analysis, profitability, liquidity.

\section{Introduction}

Many studies revealed the fact that mergers and acquisitions (M\&A) is a risky business as corporate strategy. The corporate evaluations show that most of the companies which have completed M\&A transactions disappoint to deliver on promised financial performance. There are many aspects underlying an M\&A transaction - the success or failure of acquirer companies depending on the appropriate adaptation to the business strategy. Mergers and Acquisitions (M\&A) is an important financial tool that enables companies to grow faster and provide returns to owners and investors (Sherman 2011). M\&A refers to the change in ownership, business mix, assets mix and alliance with the view to maximizing shareholders' value and improve the firms' performance (Pazarkis,
Samiya Mubeen

Research Scholar

Canara Bank School of Management Studies"
Dr. Y. Nagaraju

Canara Bank School of Management Studies

Bangalore-560001 
Vogiatzoglo, Christodoulou \& Drogalas, 2006; Gaughan, 2011; Nakamura, 2015). One of the main elements of improving company performance is the boom in mergers and acquisitions (Pazarkis et al., 2006; Gaughan, 2011; Nakamura, 2015). However, in many cases, M\&A are often used interchangeably. According to (Ross, Westerfield, Jordan, \& Etling (2003), a merger is the complete absorption of one firm by another, wherein the acquiring firm retains the identity and the acquired firm ceases to exist. It is a corporate strategy usually done between two or more companies whereby the acquiring firm and the acquired firm stand on a merger agreement. The acquisition, on the other hand, occurs when an entity purchases all or some assets such as equipment or a business unit of another (Pazarkis et al., 2006; Sherman, 2011; Gaughan, 2011; Nakamura, 2015).

Financial performance analysis must also include consideration of strategic and economic developments for the firm's long-run success. Financial managers, as well as general senior managers, are demanding evaluative standards by which they can rapidly measure the firm's performance and chart an appropriate course. These metrics should immediately provide actionable feedback to improve the operations of the firm. Management's intense interest in financial performance metrics has dramatically risen as more and more annual and long-term incentive compensation is tied to attaining acceptable levels of performance as measured by financial performance metrics.
Performance is the process of quantifying the efficiency and effectiveness of an action. Organizational performance is achieved by comparing the value that an organization creates using its productive assets with the value that owners of these assets expect to obtain (Armstrong \& Baron, 2005). Financial performance measures provide a valuable tool to the different stakeholders of a firm. Internally, these measures may be utilized by the management and existing shareholders to evaluate the past financial performance and the current financial position of a firm. Alternatively, it can also be used by potential shareholders and financial analysts to predict future financial performance (Brigham \& Houston, 2009). Financial performance is based on the idea that an organization is a voluntary collaboration of productive assets to accomplish a mutual purpose. These assets consist of human, physical and capital resources (Alchian \& Demsetz, 1972; Barney, 1991; Jensen \& Meckling, 1976).

Those supplying the assets will only commit them to the organization as long as they are content with the value they receive in exchange, relative to alternative uses of the assets. Consequently, the essence of performance is the creation of value (Alchian \& Demsetz, 1972; Barney, 1991; Jensen \& Meckling, 1976). As long as the value created through the use of the contributed assets is equivalent to or greater than the value anticipated by those contributing the assets, the assets will continue to be availed to the organization (Bacidore, Boquist, Milbourn, \& Thakor, 1997). If the assets created improve the 
performance, the organization will retain its existence. Therefore, value creation, as per definition of the resource provider, is the essential overall performance criterion for any organization (Alchian \& Demsetz 1972; Barney, 1991; Jensen \& Meckling, 1976). Three profitability measures that are universally accepted for their value to management are return on assets (ROA), return on equity (ROE), and operating profit margin.

\section{Theoretical framework}

There are many variables that define the financial performance. The above diagram depicts the overview of financial performance in a very broad way. Synergy, cost efficiency, and diversification are considered more in any of the M\&A processes. Synergy plays a very important and effective role in the process. Synergy as the interaction of two or more intellectual resources from previous autonomous organizations that enhance the combined effect of value creation and competitive performance; the effect of which is greater than the sum of the individual effects. Cost efficiency effects of merger and acquisition may depend on the type of merger and acquisition, the motivation behind it and the manner in which the management implement its plans. The cost efficiency analysis implies that financial institutions are being ranked according to their relative performance to the best practice institution in terms of managing the operating costs of producing the same output under the same conditions, such as output quality, production function, and market conditions. According to Mueller (2004), diversification is a way to decrease the risk involved in the existing operations of the business. Montgomery (1994) identifies three primary reasons that drive companies to implement diversification strategies. First is market-power belief which assumes that as a firm becomes a conglomerate, it can obtain the stronger position. Second is the agency attitude; this assumes that managers implement diversification to uplift the status of the firm and also reduce the risk of financial volatility in times of economic turbulence. The third is the resource - based view that encourages firms to diversify when they have excess resources as these resources may be utilized elsewhere to improve the firms' productivity thereby improving performance. All these variables lead to influence the performance under major three more parameters viz., profitability, liquidity, and economic growth which inturn impact the financial performance.

\section{Review of literature}

Joshi, Vyas \& Shukla(2013) conducted a study on the effect of merger and acquisition on the efficiency of performance of Indian Banks. A sample of four banks namely HDFC, ICICI, IDBI \& Federal Bank was chosen and secondary data were collected from different sources like annual reports, company websites collected, etc. To analyze the data of pre and post-merger performance, various financial ratios were used. Interpretation of the results suggested that HDFC 
\& IDBI bank shown increased profitability after merger resulting in payment of higher dividend to shareholders, while ICICI bank shown slightly low profitability performance in the post-merger period.

Verma \& Sharma (2014) reviewed the impact of a merger on the financial performance of Indian telecom sectors involved in M\& A during 20012008. A Sample size of 59 companies which had undergone merger and acquisitions deal from 2001-02 to 2007-08 have been selected. Secondary data are extracted for six years from CMIE database PROWESS. The study used regression model and various financial ratios to analyze the data that depicted the acquirer firms have leverage synergies but eventually lead to decrease the Return on Shareholder's funds after merger and acquisitions. Overall financial performance in significantly improved in postmerger period.

Joash \& Njangiru (2015) in their research study, "The Effect of Mergers and Acquisitions on Financial Performance of Banks (A survey of Commercial Banks in Kenya)", evaluated the implications of mergers and acquisitions on profitability \& shareholders' value in banking sectors by selecting a sample of 14 banks which undergone mergers or acquired during the period 2000-2014. The study was analyzed with primary data collected via open and closed ended questionnaire. Statistical tool viz.,coefficient of correlation was used in the study that concluded the shareholders' value increased by acquiring firms after a merger.
Agarwal \& Singh (2015) conducted a case study on the effect of the merger on the financial performance of Kingfisher Airlines; the objective of the study was to analyze the pre \& post-merger of the financial performance of KFA (Kingfisher Airlines).The study used accounting ratios in terms of profitability, liquidity, earning per share, leverage to evaluate the data. With the statistical technique as paired t-test used to conclude the result which found no improvement and benefit in acquiring firm (KFA) after a merger, as well no significant result shown in return on equity and earnings per share.

Nasieku \& Susan (2016) made a study on the effect of financial restructuring on the financial performance of firms in Kenya. Based upon three theories namely Resource based view theory, Life cycle theory \& Static trade off- theory and vast analyzed of past literature review the researcher concludes optimum and appropriate financing mix or proper balance of equity $\&$ debt funds ensures a good return to shareholders.

Harwood, Nakola \& Nyaana (2016) examined the effects of organizational restructuring on the financial performance of National Bank of Kenya. The specific objective of the study is to determine the relationship between organizational restructuring and financial performance. A sample size of 18 respondents out of total population of 54 respondents used in the study. Both primary and secondary data were collected by well-structured questionnaire and published financial statements respectively. Inferential statistical tools such as Factor analysis, Retest method, Simple regression 
model and Pearson correlation method used in the study to attain the objective. The study concludes financial performance is positively affected by organizational restructuring although not statistically significant.

Yusuf (2016) examined the post-merger financial health of Jordanian industrial sectors where in seven firms selected as the sample size for the study involved in financial restructuring deal from period 2000 and 2014. The study analyzed the collected secondary data from various annual published financial statements. Using financial ratios and statistical technique as parametric t-test to assess the significance of prepost financial performance of selected firms. Authors concluded that there was insignificant improvement seen or found in the post-merger period. Liquidity, profitability, and market share showed no improvement in the selected manufacturing firms after merger and acquisitions deals.

\section{Need for the Study}

There is no doubt that M\&As have been and continue to be a popular strategic alternative to organization growth. Very few study done on the various factors, but for the study few prime causes like profitability, liquidity and economic growth have taken for the analysis to determine the M\&Aperformance.

\section{Objectives}

- To analyze the pre and post-merger of Profitability Liquidity and growth position of the select companies.
- To examine the impact of merger and acquisitions on financial performance in the select company.

\section{Research Design}

The theoretical framework is a structure that identifies and describes the major theories that organize a study Smith (2004). It is used to hypothesize, understand, or give meaning to the relationships among the elements that influence, affect, or predict the events or outcomes specified Kombo and Tromp, (2009). The theoretical framework grows out of the research focus, guides the design of individual studies, and structures the research presentations and publications. The theoretical framework provides a well - supported rationale to conduct the current study and helps the readers understand the student's perspective. A good theoretical framework assures the reader that the type of investigation is not based solely on personal instincts or guesses, but rather informed by established theory and empirical facts obtained from credible studies Creswell (2012). These variables were factored and regressed to get the latent variables (profitability, liquidity and economic growth). The methodology is an exploratory and descriptive in natures of the selected companies. The study conducted on ten companies as selected by the sample size. Convenience and Judgmental sampling technique have been used to select the sample of the companies. Table I represent the operating financial performance of selected companies 
reveals Gross profit ratio of selected ten companies declines after M\&A. Out of ten companies decreased gross profit, five companies gross profit margin statistically significantly deteriorated. Net profit ratio of only four firms improved while others six companies showed decreases. Out of six decrease net profit margin firms, all the six companies' net profit margin statistically significantly declines. Operating margin of one firm shown improved out of ten companies. Out of rest selected nine firms' declines sampling techniques have been employed to represent the companies in the better way and show the better relationship with other variables. A total ten Companies deals merger in India has been selected as sample size.

- Indian Oil Corporation

- Reliance Industries

- Bharat Petroleum Corporation

- Zee Entertainment Enterprises

- Jyothy Laboratories

- Tata Consultancy Services

- Satyam Computer Services

- Tech Mahindra

- Network 18

- Sahara India

Secondary data collected from an audited published annual financial statement, Fortune India 500 list and investment sites for the period covering from 2001-2017. Under this study, selected sample units merged and acquired in the year considered as zero (0). To analyses, the effect of M\&A's on the financial status, on the basis of averages for a set of financial key ratios were determined for five years pre and post taking the merger completion year as 0 . The statistical tools to determine the result about the implication of business merged on the financial performance of acquired companies the analysis of the present study uses the known financial ratios for assessing the firm's performance. A company's profitability is judged or measured by five financial ratios. Gross Profit Ratio (GPR \%), Net Profit Ratio (NPR \%), Operating Profit Ratio (OPR \%), Return on Capital Employed (ROCE\%), Earning Per Share (EPS) \%. To measure leveraged of selected companies by Current Ratio (CR), Quick Ratio (QR), DebtEquity Ratio (D-E) and popularly known statistical tool as the paired sample " $\mathrm{t}$ " test were applied. Data collected has been analyzed with the help of SPSS.

Research Gap: Many studies have been conducted on sector wise where the pre and post financial performance analysis and the comparison are done for three years, but in this paper, an attempt is made in order to analyze the overall impact on M\&A towards the financial performance of select Indian companies for 5 years. To ascertain this hypothesis is framed.

\section{Hypothesis:}

$\mathrm{H}_{1}$ : Merger and acquisitions have a significant impact on profitability, liquidity and economic growth indicators of selected companies.

$\mathrm{H}_{2}$ : Merger and acquisitions have no effect on the financial performance of the selected companies. 


\section{Data Analysis \& Interpretation}

\begin{tabular}{|c|c|c|c|c|c|c|c|c|c|c|c|c|c|c|c|}
\hline \multirow[b]{2}{*}{ Company } & \multicolumn{12}{|c|}{ Table 1: Impact of Merger on Profitability } & \multicolumn{3}{|c|}{ ROCE \% } \\
\hline & Pre & Post & Sig & Pre & Post & Sig & Pre & Post & Sig & Pre & Post & Sig & Pre & Post & Sig \\
\hline$+\infty$ & & & & & & & & & & & & & & & \\
\hline & 35.87 & 33.25 & & 14.16 & & .069 & 22.89 & 14.9 & .003 & 16.42 & 7.73 & .016 & 18.59 & 12.27 & .281 \\
\hline \begin{tabular}{|l|} 
Reliance \\
Industries
\end{tabular} & & & & & & & & & & & & & & & \\
\hline & 31.16 & 17.12 & .298 & 22.53 & 12.74 & .001 & 32.06 & 31.7 & .980 & 29.6 & 12.7 & .040 & 33.7 & 15.0 & .089 \\
\hline $\begin{array}{l}\text { Bharat } \\
\text { Petroleum } \\
\text { corporation }\end{array}$ & 22.69 & 12.05 & .001 & 13.16 & 10.33 & .069 & 22.89 & 14.9 & .003 & 16.42 & 7.73 & .016 & 13.59 & 11.22 & 291 \\
\hline \begin{tabular}{|l} 
Zee \\
entertainment \\
Enterprises
\end{tabular} & 23.72 & 1.24 & .069 & 18.77 & -4.98 & .001 & 25.03 & 4.10 & .003 & 30.27 & 2.19 & .003 & 35.58 & \begin{tabular}{|l|} 
\\
\end{tabular} & .003 \\
\hline $\begin{array}{l}\text { Jyothy } \\
\text { Laboratories }\end{array}$ & 51.08 & 50.54 & & 25.8 & 29.4 & .38 & 51.7 & 60.4 & .019 & 36.6 & 30.4 & .102 & 84.14 & 43.3 & .046 \\
\hline $\begin{array}{l}\text { Tata } \\
\text { Consultancy } \\
\text { Services }\end{array}$ & 7.95 & 6.73 & .41 & 7.27 & 4.15 & .091 & 10.30 & 9.66 & .623 & 23.75 & 10.46 & .029 & 47.4 & 23.9 & .233 \\
\hline \begin{tabular}{|l} 
Satyam \\
Computer \\
Services
\end{tabular} & 23.34 & 1.21 & .062 & 18.47 & -4.98 & .001 & 22.03 & 3.10 & .003 & 32.27 & 2.19 & .003 & 30.58 & \begin{tabular}{|l|} 
\\
\end{tabular} & .003 \\
\hline Tech Mahindra & 32.47 & 31.25 & .001 & 12.16 & 0.33 & .069 & 20.89 & 11.9 & .003 & 11.42 & 4.73 & .016 & 12.59 & 11.27 & .276 \\
\hline Network 18 & 22.16 & 11.12 & 298 & 21.53 & 10.74 & .001 & 22.06 & 21.7 & .910 & 21.6 & 12.7 & .040 & 30.7 & 11.0 & .089 \\
\hline Sahara India & \begin{tabular}{|l|}
.61 \\
\end{tabular} & -1.9 & .60 & -1.2 & 1.7 & .54 & .87 & $\mid-1.47$ & .64 & 10.99 & 5.15 & .38 & 6.9 & 2.27 & .26 \\
\hline
\end{tabular}

(Source:Fortune India 500 List, www.moneycontrol.com and calculated values by using SPSS)

Pre and post-merger average ratios are determined by each company selected in the sample size. Profitability and Liquidity position of each firm is separately analyzed in prior and post-merger of ten companies. Operating profit, five companies operating profit statistically significantly deteriorated. Selected ten companies ROCE declines and shown no improvement after M\&A. Out of ten decreased return on capital employed eight companies ROCE statistically significantly fallen. All selected ten companies earning per share have shown no improvement. Out of declines earning per share of ten companies seven firms EPS significantly deteriorated after business merged. At the end, the study observed or determined that financial synergies i.e. the profitability position after merger does not show improvement of the acquirer firms under the present study. Therefore, $\mathrm{H} 1$ is not accepted that merged corporate has a significant effect on the operating and profitability performance of acquired companies 
Table 2: Impact of Merger \& Acquisitions on Liquidity

\begin{tabular}{|c|c|c|c|c|c|c|c|c|c|}
\hline \multirow{2}{*}{ Company } & \multicolumn{3}{|c|}{ Current Ratio } & \multicolumn{3}{|c|}{ Quick Ratio } & \multicolumn{3}{|c|}{ Debt-Equity Ratio } \\
\hline & Pre & Post & Sig & Pre & Post & Sig & Pre & Post & Sig \\
\hline Indian Oil Corporation & .52 & .80 & .015 & 1.19 & 1.09 & .89 & .40 & .29 & .041 \\
\hline Reliance Industries & .57 & .86 & .011 & 1.10 & 1.03 & .87 & .39 & .23 & .031 \\
\hline $\begin{array}{l}\text { Bharat Petroleum } \\
\text { corporation }\end{array}$ & 1.12 & 1.06 & .66 & .65 & .53 & .62 & .53 & .27 & .047 \\
\hline $\begin{array}{l}\text { Zee entertainment } \\
\text { Enterprises }\end{array}$ & 1.69 & 1.1 & .18 & 2.01 & 2.01 & 1.0 & .32 & 1.15 & .056 \\
\hline Jyothy Laboratories & 1.36 & 1.23 & .15 & 1.31 & 1.17 & .07 & .22 & .076 & .12 \\
\hline $\begin{array}{l}\text { Tata Consultancy } \\
\text { Services }\end{array}$ & .85 & .48 & .121 & .84 & .47 & .048 & .64 & .80 & .566 \\
\hline $\begin{array}{l}\text { Satyam Computer } \\
\text { Services }\end{array}$ & 1.69 & 1.0 & .13 & 2.03 & 2.03 & 1.0 & .30 & 1.12 & .048 \\
\hline Tech Mahindra & 1.26 & 1.23 & .16 & 1.30 & 1.12 & .08 & .24 & .079 & .12 \\
\hline Network 18 & .89 & .49 & .124 & .89 & .49 & .045 & .68 & .89 & .57 \\
\hline Sahara India & 2.16 & 1.26 & .48 & 3.5 & 2.3 & .49 & 1.7 & .54 & .36 \\
\hline
\end{tabular}

(Source:Fortune India 500 List, www.moneycontrol.com and calculated values by using SPSS

Table 2 reveals the liquidity of selected companies reveals the current ratio of only one firm has shown improvement out of ten companies and rest nine current ratio declines after the merger. And the rest nine decreased current ratio statistically significantly deteriorated. A quick ratio of one company remains stable and none other firms shown improvement in quick ratio. At the same time out of nine decreased quick ratio indicators, seven companies' quick ratios statistically significantly deteriorated. Debt- Equity ratio of only four firms improved and six sample of D-E ratio falls. Out of four firms improved debt-equity ratio only one firm debt-equity ratio statistically significant. And four out of six selected companies decreased debt- equity ratio is statistically significantly deteriorated. Finally, it is determined that post-merger liquidity position indicators deteriorated after an overall comparing the improvement and deterioration indicators. It is observed that pre-liquidity position was better before merger. Thus, $\mathrm{H} 2$ is rejected that Merger and acquisitions have a significant impact on liquidity indicators of selected firms in the sample.

\section{Managerial Implications}

M\&A is a strategic move which commonly used worldwide in order to achieve growth and profitability to the organization. When M\&A happens manager has to be given more importance for the financial aspects so that profitability can be enhanced by the organization. The finance aspects suggest that finance has a significant effect (reflected by the manifest variables: acquisition premium, bidding process, and due diligence, exchange rates, cost efficiency) on M\&A financial performance reflected on synergy . the effect of cost efficiency on the financial performance of merged financial institutions and found out that there is the significant relationship between cost efficiency and financial performance of merged 
institutions. The implication is that a high degree of cost efficiency improves performance in terms of profitability. mergers and acquisitions lead to a high level of cost efficiency due to the fact that the merged company makes use of less cost, manpower, management effort and financial resources to generate the maximum level of output after the merger. The cost efficiency of the company has a positive impact on the profitability of the company, return on assets (ROA) and return on equity (ROE) of the company.

\section{Limitations of the Research}

The limitation of the study is, select Indian companies from Fortune 500 list only 10 companies have taken for the study, the extent of the database and the timeframe. Moreover, single key informants were utilized for the collection of the secondary data. Each of these limitations could influence the validity of the outcomes. Nevertheless, all effort was made to ensure that the outcomes' data quality was satisfactory.In respect of the model as it was used in this study, which revealed different constructs and underlying manifest variables that are important in explaining M\&A financial performance.

\section{Suggestions for Future Research}

The further research, it is tantalizing to note that strategic logic and organizational behavior aspects seem to lead to improved financial performance. Future research could lead to additional variables being revealed or even new perspectives, and establish their importance regarding $\mathrm{M} \& \mathrm{~A}$ financial performance. By increasing the sample size from ten companies to more findings may vary. The study can be conducted on sector wise pre and post analysis of M\&A can be done for 20 years.

\section{References}

Alchian, A.A. \& Demesetz, H., (1972) Production, information costs, and economic organization. American Economic Association, 62 (5), 777-795

Armstrong, M. \& Baron, A. (2005) Managing performance: performance management in action. London, UK: CIPD

Ashutosh, Joshi Garima, Dr. Rajeev Shukla. A study on the impact of merger and acquisitions on the efficiency of performance of Indian banks. Altius Shodh Journal of Management \& Commerce. ISSN: 23488891.

Agarwal Megha, Singh Shikha. Effect of Merger on Financial Performance: A case Study of Kingfisher Airlines. XVI Annual Conference Proceeding. ISSN: 978-81-923211-7-2. 2015; pp.399-413.

Barney, J. (1991). Firm resources and sustained competitive advantage. Journal of Management, 17(1), 99-120.

Brigham, E.F., \& Houston, J.F. (2009). Fundamentals of financial management: Concise third edition. Mason, Ohio: SouthWestern College Publications.

Bacidore, J. M., Boquist, J. A., Milbourn T. T., \& Thakor A. V. (1997). The search for the best financial performance measure. Financial Analysts Journal, 53(3), 11-20.

Creswell, J.W. (2012). Educational research: Planning, conducting, and evaluating quantitative and qualitative research. Upper Saddle River, NJ: Prentice Hall

Gaughan, P. A(2002). Mergers, Acquisitions and Corporate Restructurings. 3rd Ed. New Jersey, NY: John Wiley and Sons 
Gaughan, P.A. (2011). Mergers, Acquisitions and Corporate Restructurings. 5th Ed. New Jersey, NJ: John Wiley \&Sons

Harwood Isabwa, Nakola Joel, Nyaana Derek. Effects of organizational restructuring on firm performance: A case of National Bank of Kenya. Global Journal of Advanced Research. ISSN: 2394-5788. 2016; 3(1):4349.

Hroot, Dr. Yusuf Ali. The Impact of Mergers on Financial Performance of the Jordanian Industrial Sector. International Journal of Management and Business Studies. ISSN: 2230-9519. 2016; 6(1):9-13.

Joash Gwaya Ondieki, Njangiru Mungai John. The Effect of Mergers and Acquisitions on Financial Performance of Banks (A survey of Commercial Banks in Kenya). International Journal of Innovative Research and Development. ISSN: 2278-0211. 2015; 4(8):101-113

Jensen, M. C. \& Meckling W. H. (1976). Theory of the Firm: Managerial Behavior, Agency Costs, and Ownership Structure. Journal of Financial Economics, 3(4), 305-360

Kombo, D.K., \& Tromp, D.L.A. (2009).Proposal and Thesis Writing: An Introduction. Paulines Publications Africa, Don Bosco Printing Press, Nairobi Kenya

Mueller, D. C. (2004). Efficiency versus Market Power through Mergers. The International Handbook of Competition; Edward Elgar.

Montgomery, C. (1994). Corporate Diversification. Journal of Economic
Perspectives, 8 (3), 163-178 restricting on financial performance firms in Kenya. International Journal of Management and Economics Invention, ISSN: 2395-7220. 2016; 2(1):487-495.

Nakamura, R. (2015). To merge and acquire when the times are good? The influence of macro factors on the Japanese M\&A pattern. The ICFAI Journal of Mergers and Acquisitions, 2 (2) 15-33.

Pazarskis, M., Vogiatzogloy, M., Christodoulou, P. \& Drogalas, G. (2006). Exploring the Improvement of Corporate Performance after Mergers -the Case of Greece, International Research Journal of Finance and Economics, 6:184-192.

Ross, S. A., Westerfield, R.W. and Jordan B. D,\& Etling C. (2003), Essentials of Corporate Finance, USA, US: McGraw-Hill Higher Education.

Sherman, A. J.(2011). Mergers \& Acquisitions: Retrieved from A to $Z$ : USA: AMACOM.Div. American Mgmt Assn

Smith, R.L. (2004). Entrepreneurial Finance. (2nd ed.). New York: John Wiley and Son

Verma Neha, Dr. Rahul Sharma. Impact of Mergers \& Acquisitions on Firms, Long Term Performance: A Pre \& Post Analysis of the Indian Telecom Industry. International Journal of Research in Management \& Technology. ISSN: 2249-9563. 2014; 4(1):11-19. 